\title{
PENGARUH TEMPERATUR TERHADAP PENGERINGAN BUAH MANGGA PADA CABINET DRYER
}

\author{
Susilawati ${ }^{1}$, Muslikhin Hidayat ${ }^{2}$, Prajitno ${ }^{3}$ \\ ${ }^{1}$ Jurusan Teknik Refrigerasi dan Tata Udara, Politeknik Negeri Bandung \\ ${ }^{2}$ Jurusan Teknik Kimia, Universitas Gadjah Mada \\ ${ }^{3}$ Jurusan Teknik Mesin dan Industri, Universitas Gadjah Mada \\ Email: susilawati@polban.ac.id
}

\begin{abstract}
ABSTRAK
Buah mangga (Mangifera indica Linn) merupakan komoditas musiman dan memiliki umur simpan yang pendek, sehingga untuk dapat menikmati produk buah mangga sepanjang tahun diperlukan proses pengawetan. Pengeringan menggunakan cabinet dryer merupakan salah satu cara untuk mengawetkan buah mangga. Variabel penelitian ini meliputi: variabel bebas yaitu temperatur $\left(40,50,60,70\right.$ dan $\left.80^{\circ} \mathrm{C}\right)$, variabel terikat yaitu kandungan air, kecepatan pengeringan dan efisiensi pengeringan, dan variabel kontrol yaitu waktu pengeringan buah (5 jam) dan debit aliran udara $0,0234 \mathrm{~m}^{3} / \mathrm{s}$, konsentrasi larutan gula ( $50 \%$ selama 4 jam pada temperatur ruang) dan konsentrasi larutan kapur (2\% selama 15 menit). Hasil penelitian menunjukkan bahwa makin tinggi temperatur semakin banyak kandungan air yang teruapkan, dan pengeringan yang optimal diperoleh pada temperatur $70^{\circ} \mathrm{C}$ dengan pencapaian efisiensi $22,79 \%$ dengan penggunaan kalor untuk memanaskan bahan sebesar 25,5 kJ, kalor untuk memanaskan air sebesar 1,2 kJ, kalor untuk menguapkan air 63,4 kJ, kalor untuk memanaskan udara $238,7 \mathrm{~kJ}$ dan kalor yang diterima oleh cabinet dryer $12.932,5 \mathrm{~kJ}$.

Kata kunci: pengeringan, cabinet dryer, temperatur, mangga

Mango (Mangifera indica Linn) is seasonal commodity with short storage time. Therefore, it needs preservation in order to consume mango product year-round. Drying process using cabinet dryer in one of mango preservation method. Experiment variable settings are: free variable of temperatures were $40,50,60,70$ and $80^{\circ} \mathrm{C}$ ), fixed variable of water content, drying speed and efficiency, and controlled variabel of mango drying time for 5 hours, and air flow debit of $0,0234 \mathrm{~m}^{3} / \mathrm{s}$, sugar solution concentration (50\% during 4 hours in room temperature) and lime solution concentration (2\% during 15 minutes). The result of the experiment showed that the increasing of temperature affected to more water content vaporized. Optimal drying obtained at temperature of $70{ }^{\circ} \mathrm{C}$ with $22,79 \%$ efficiency, and the heat needed to heat the material was $25,5 \mathrm{~kJ}$, the heat to increase water temperature was $1,2 \mathrm{~kJ}$, the heat to vaporize water was $63,4 \mathrm{~kJ}$, the heat to increase air was $238,7 \mathrm{~kJ}$ and the heat pass through cabinet dryer was $12932,5 \mathrm{~kJ}$.
\end{abstract}

Kata kunci: pengeringan, cabinet dryer, temperatur, mangga

\section{PENDAHULUAN}

Indonesia negara yang memiliki iklim tropis menjadikannya kaya akan hasil bumi. Salah satu komoditas pertanian yang berlimpah di Indonesia adalah buah mangga. Buah mangga tidak tumbuh sepanjang tahun dan mempunyai umur simpan tertentu. Salah satu cara untuk dapat menikmati buah mangga setiap saat dengan cara pengawetan. Secara tradisional pengawetan menggunakan bantuan sinar matahari yaitu pengeringan atau penjemuran di bawah sinar matahari, akan tetapi hal tersebut memerlukan waktu yang cukup lama dan sangat tergantung pada cuaca sehingga diperlukan suatu teknologi untuk dapat mengeringkan buah dengan waktu relatif pendek dan tidak tergantung pada cuaca. Teknologi pengeringan yang dapat digunakan saat ini yaitu Cabinet Dryer. Berdasarkan uraian tersebut, maka perlu suatu penelitian tentang "Pengaruh Temperatur terhadap Pengeringan Buah Mangga pada Cabinet Dryer"

Rumusan masalah pada penelitian ini ketika cuaca sedang tidak mendukung maka diperlukan pengetahuan mengenai temperatur pengeringan sehingga tidak memerlukan waktu berhari-hari untuk mengeringkan buah mangga.

Batasan pada penelitian ini adalah buah yang digunakan adalah jenis harum manis dengan asumsi umur panen sama dan kerugian panas tidak diperhitungkan. Proses pengeringan ini menggunakan prototype cabinet dryer. 


\section{METODOLOGI}

\section{Penentuan Variabel}

Penelitian ini merupakan penelitian eksperimental dengan beberapa variabel, diantaranya:

1. Variabel Bebas

Variabel bebas adalah faktor yang diukur untuk menentukan hubungan antara gejala yang terjadi saat penelitian. Variabel bebas pada penelitian ini adalah temperatur dengan level temperatur adalah : 40, 50, 60, 70 dan $80^{\circ} \mathrm{C}$

2. Variabel Terikat

Variabel terikat adalah faktor yang diobservasi dan diukur untuk menentukan pengaruh variabel bebas. Variabel terikat dari penelitian ini adalah kandungan air.

3. Variabel Kontrol

Variabel kontrol adalah variabel yang menjadi kendali pada setiap perlakuan. Adapun variabel kontrol untuk penelitian ini adalah

a. Waktu pengeringan selama 5 jam dan debit aliran udara $0,0234 \mathrm{~m}^{3} / \mathrm{s}$.

b. Konsentrasi larutan gula adalah $50 \%$ selama 4 jam pada temperatur ruang $\left(28^{\circ} \mathrm{C}\right)$.

c. Konsentrasi larutan kapur yaitu $2 \%$.

\section{Peralatan dan Bahan}

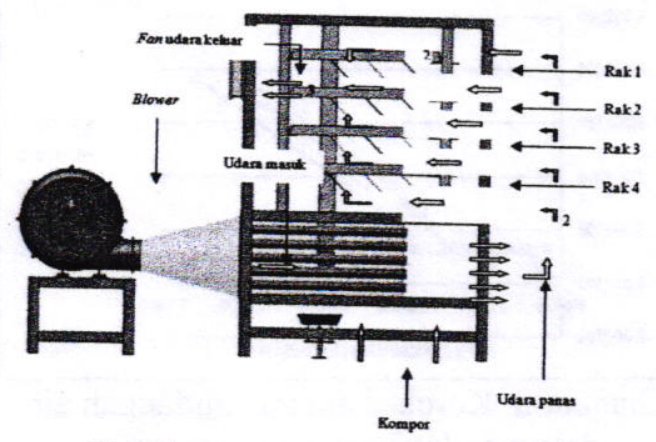

Gambar 1. Prototipe Cabinet Dryer

Cara kerja dari prototipe cabinet dryer adalah:

a. Kompor mengalirkan kalor melalui pipapipa pada ruang bakar ;

b. Blower mendorong kalor menuju ruang pengering;

c. Aliran udara panas mengalir pada ruang pengering yang memiliki 4 rak yang berisi buah mangga yang akan dikeringkan;

d. Pengukuran temperatur dilakukan pada rak atas dan rak bawah (2) dengan mengukur temperatur kering dan basahnya menggunakan thermometer; e. Uap air hasil pengeringan dikeluarkan melalui saluran keluaran (3);

f. Pengaturan temperatur dilakukan secara manual dengan pengaturan api kompor gas.

Bahan utama pada penelitian ini adalah buah mangga dengan bahan tambahan gula pasir \& kapur (larutan kapur untuk makanan)

\section{Alur Penelitian}
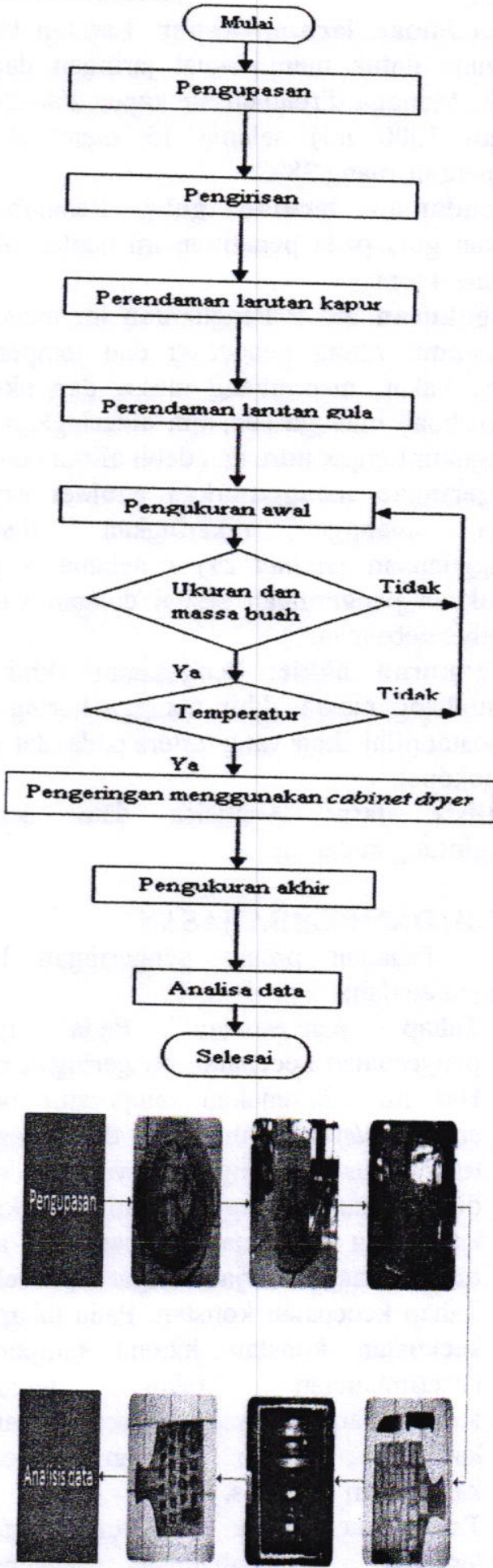

Gambar 2. Alur Penelitian 
Keterangan:

Pengupasan: Sebelum pengupasan dilakukan, terlebih dahulu dilakukan pencucian. Buah mangga dikupas sehingga tidak terlihat kulit buahnya. Kemudian dilakukan pencucian kembali sehingga getahnya dapat dihilangkan.

Pengirisan: Keseragaman pengukuran daging buah dilakukan irisan dengan ukuran $3 \mathrm{~cm} \times 2$ $\mathrm{cm} \times 0,5 \mathrm{~cm}$ dengan massa mangga antara $2.5-$ 3 gram.

Perendaman larutan kapur: Larutan kapur berguna untuk memperkuat jaringan daging buah. Mangga direndam air kapur 2\% (20 gr dalam $1000 \mathrm{ml}$ ) selama 15 menit dalam temperatur ruang $28^{\circ} \mathrm{C}$

Perendaman larutan gula: Penambahan larutan gula pada penelitian ini adalah $50 \%$ selama 4 jam.

Pengukuran awal: Pengukuran ini mencatat temperatur ruang pengering dan temperatur ruang bakar, menimbang massa dan ukuran irisan buah mangga sebelum dikeringkan dan mengukur temperature dan debit aliran udara.

Pengeringan menggunakan cabinet dryer: Buah mangga dikeringkan dengan menggunakan cabinet dryer selama 5 jam. Perlakuan pengeringan sesuai dengan variasi variabel bebasnya.

Pengukuran akhir: Pengukuran akhir ini menimbang massa akhir mangga kering dan mencatat nilai akhir yang tertera pada alat ukur termokopel.

Analisis data: Analisisa data dengan menghitung kadar air.

\section{HASIL DAN PEMBAHASAN}

Tahapan proses pengeringan buah mangga adalah:

a. Tahap penyesuaian. Pada tahap penyesuaian kecepatan pengeringan naik. Hal ini dikarenakan temperatur udara cabinet dryer lebih tinggi dibandingkan temperatur mangga yang akan dikeringkan, sehingga terjadi pertukaran kalor dan kecepatan pengeringan awal turun. Tahap ini terjadi sangat cepat sekali.

b. Tahap kecepatan konstan. Pada tahap ini kecepatan konstan karena temperatur kesetimbangan telah tercapai. Kesetimbangan tersebut tercapai karena kadar air dalam padatan mencapai kandungan air kritis.

c. Tahap kecepatan menurun. Setelah tercapai kesetimbangan, kecepatan pengeringan menurun linear. $\mathrm{Hal}$ ini disebabkan lapisan permukaan cairan berkurang karena penguapan. Selanjutnya kecepatan menurun tajam (tidak linear) tergantung pada gerakan cairan melalui zat padat dikarenakan adanya perbedaan konsentrasi antara bagian dalam dengan permukaan zat yang dikeringkan.

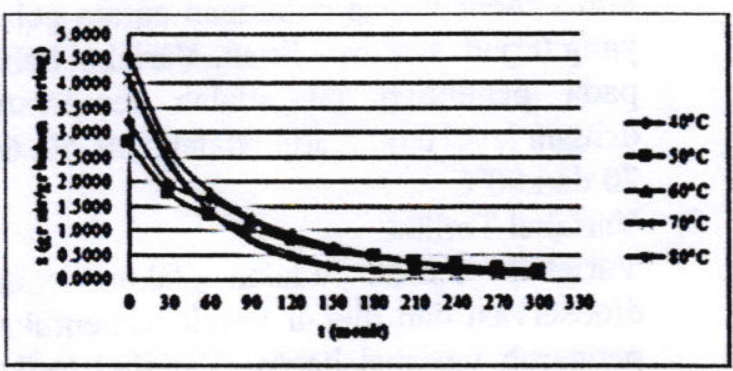

Gambar 2. Korelasi antara waktu dan kandungan air dalam padatan

Pada Gambar 2 terlihat untuk kandungan air awal dalam bahan (buah mangga) yang teruapkan terbanyak ada pada temperatur $60^{\circ} \mathrm{C}$. Semakin lama proses pengeringan maka semakin sedikit kandungan air dalam padatannya. Begitupula untuk kecepatan pengeringan dapat terlihat pada Gambar 3, temperatur paling tinggi $80^{\circ} \mathrm{C}$. Grafik ini sesuai dengan proses pengeringan bahan pangan yang berada pada kondisi temperatur panas.

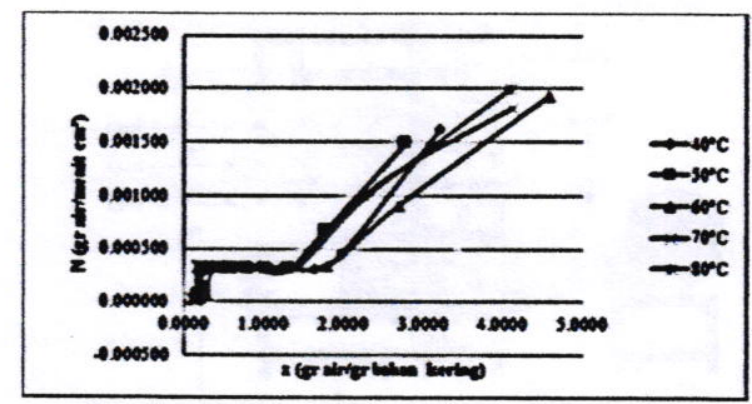

Gambar 3. Korelasi antara kandungan air dalam padatan (x) dan kecepatan pengeringan $(\mathrm{N})$

Perhitungan kalor yang dilakukan meliputi kalor untuk memanaskan bahan $\left(\mathrm{q}_{1}\right)$, kalor untuk memanaskan air $\left(\mathrm{q}_{2}\right)$, kalor untuk menguapkan air $\left(\mathrm{q}_{3}\right)$, kalor untuk memanaskan udara $\left(\mathrm{q}_{\mathrm{u}}\right)$ dan kalor yang diterima oleh cabinet drayer $\left(\mathrm{q}_{\mathrm{i}}\right)$. Sedangkan efisiensi pengeringan adalah perbandingan antara panas yang dibutuhkan secara teoritis dengan penggunaan panas aktual. 
Tabel 1. Perolehan kalor pada pengeringan buah manga

\begin{tabular}{|c|c|c|c|c|c|c|c|}
\hline 4 & $\begin{array}{l}1 \\
\text { M }\end{array}$ & (4) & $\begin{array}{l}1 \\
\text { ant }\end{array}$ & in 1 & & $4 \sqrt{\operatorname{man}}$ & 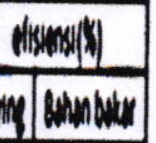 \\
\hline I & 1,854 & 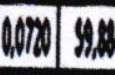 & & & & & \\
\hline$y$ & 18001 & 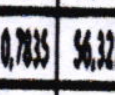 & & $\sqrt{118}$ & 24 & S114) & \\
\hline 1 & unval & (1000) & & 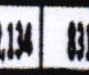 & & 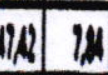 & \\
\hline$\pi$ & 8 & $120 \times 5$ & & 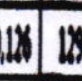 & 52012 & 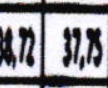 & \\
\hline $\bar{y}$ & 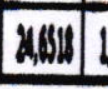 & 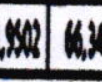 & $x$ & & & & ג \\
\hline
\end{tabular}

Efisiensi pengeringan yang paling ooptimal diperoleh pada saat temperatur $70^{\circ} \mathrm{C}$ dan konsumsi bahan bakar dari pengeringan mangga memiliki prosentase yang kecil disebabkan buah mangga yang dikeringkan dalam jumlah sedikit sehingga panas yang dihasilkan tidak digunakan dengan maksimal. Selain itu rugi-rugi kalor juga tidak dapat dipungkiri mempengaruhi karena perancangan alat yang belum optimal diantaranya rancangan konstruksi menyebabkan kalor yang dihasilkan dapat keluar sehingga sebaaran udara panas tidak merata.

\section{KESIMPULAN DAN SARAN Kesimpulan}

Berdasarkan hasil penelitian pengeringan buah mangga menggunakan cabinet dryer, dapat diambil kesimpulan sebagai berikut:

1. Temperatur berpengaruh pada proses pengeringan buah mangga. Semakin tinggi temperatur, kandungan air bahan pangan yang teruapkan semakin banyak menyebabkan produk cepat kering.

2. Efisiensi pengeringan yang optimal diperoleh pada temperatur $70^{\circ} \mathrm{C}$ mencapai $22,79 \%$ dengan perolehan kalor untuk memanaskan bahan sebesar $25,5 \mathrm{~kJ}$, kalor untuk memanaskan air sebesar $1,2 \mathrm{~kJ}$, kalor untuk menguapkan air $63,4 \mathrm{~kJ}$, kalor untuk memanaskan udara $238,7 \mathrm{~kJ}$ dan kalor yang diterima oleh cabinet drayer $12932,5 \mathrm{~kJ}$

\section{Saran}

Adapun saran-saran untuk penelitian pengeringan buah mangga menggunakan cabinet dryer adalah:

1. Dilakukan penelitian pendahuluan yang komprehensif

sehingga

dapat meminimalisasi penelitian

kesalahan prosedur

2. Pembuatan alat dilakukan dengan perancangan yang tepat sehingga rugi-rugi kalor dapat diminimalisasi

\section{DAFTAR PUSTAKA}

Anonim. 2009. Standar Prosedur Operasional Pengolahan Mangga. Departemen Pertanian, Jakarta

Afriani, L.H., 2008. Teknologi Pengawetan Pangan. Penerbit Alfabeta. Bandung.

Astutik, H.M., 2003. Pengaruh Suhu dan Lama Pengeringan Pisang terhadap Mutu Pisang Sale. Skripsi. UMM, Malang

Effendi, M.S., 2009. Teknologi Pengolahan dan Pengawetan Pangan. Penerbit Alfabeta. Bandung

Estiasih, T., \& Ahmadi Kgs., 2009. Teknologi Pengolahan Pangan. PT Bumi Aksara. Jakarta

Giraldo, G., Talens, P., Fito, P., \& Chiralt, A., 2002. Influence of Sucrose Solution Concentration on Kinetic and Yield during Osmotic Dehydration of Manggo. Jurnal. Elsevier Science LTD

Histifarina, D., 2009. Petunjuk Teknis Teknologi Pengolahan Buah Manga. Balai Pengkajian Teknologi Pertanian. Jawa Barat

Heldman, D.R., \& Lund,D.B., 2007. Handbook of Food Engineering (second edition). CRC Press. Boca Raton

Irawan, D., 2009. Pengaruh Proses Pengeringan terhadap Tingkat Keawetan Lidah Buaya (Aloe Vera). Tesis. MST UGM, Jogjakarta.

Peraturan Presiden Republik Indonesia (PP RI) Nomor 5 Tahun 2010 tentang Rencana Pembangunan Jangka Menengah Nasional (RPJMN) Tahun 2010 - 2014. 2010. Memperkuat Sinergi Antarbidang Pembangunan. Bab X Sumber Daya Alam dan Lingkungan Hidup. Kementerian Perencanaan Pembangunan Nasional.

Rukmana, R., 1996. Seri Budi Daya: Mangga. Penerbit Kanisius. Yogyakarta

Suarnadwipa, N., \& Hendra W., 2008. Pengeringan Jamur dengan Dehumidifier. Jurnal Ilmiah Teknik Mesin CAKRAM Vol 2 No 1 
Sudarmadji, S., Haryono, B., \& Suhardi., 1996. Analisa Bahan Makanan dan Pertanian. Liberty. Yogyakarta

Supriyono., 2003. Mengukur Faktor - faktor dalam Proses Pengeringan, Depdiknas, Jakarta

Taib, G., Said, G., \& Wiraatmadja, S., 1987. Operasi Pengolahan pada Pengolahan Hasil Pertanian. PT Mediyatama Sarana Perkasa. Jakarta
Treybal, R.E., 1981, "Mass Transfer Operation", Mc Graw-Hill Book Company, Inc., Singapore.

Yani, E., Abdurrahim., \& Pratoto, A., 2009. Analisis Efisiensi Pengeringan Ikan Nila pada Pengeringan Surya Aktif Tidak Langsung. Jurnal. Teknik Mesin, Universitas Andalas, Padang 